\title{
The Effect of Fermentation Time on the Nutritional Value of Sago Hampas
}

\author{
Heru Ponco Wardono ${ }^{1,2}$, Ali Agus ${ }^{2, *}$, Andriyani Astuti ${ }^{2}$, Nono Ngadiyono ${ }^{3}$ and \\ Bambang Suhartanto ${ }^{2}$
}

\author{
${ }^{I}$ North Maluku Assesment Institute for Agricultural Technology, Jl. Poros Sofifi-Weda, Kusu, Oba Utara, Tidore \\ Kepulauan 97827, Maluku Utara, Indonesia. \\ ${ }^{2}$ Departemen of Animal Nutrition and Feed Science, Faculty of Animal Science, Universitas Gadjah Mada, Jl. Fauna \\ No. 3, Bulak Sumur, Sleman 55281, Yogyakarta, Indonesia. \\ ${ }^{3}$ Departemen of Animal Production, Faculty of Animal Science, Universitas Gadjah Mada, Jl. Fauna No. 3, Bulak \\ Sumur, Sleman 55281, Yogyakarta, Indonesia. \\ * Corresponding author: Email: aliagus@ugm.ac.id
}

\begin{abstract}
Agricultural waste such as sago hampas has a great potential to suffice the requirements of cattle feed availability in Indonesia. This research aims to determine the quality of sago hampas fermented with multi microbial inoculum and additional urea with a long fermentation time. The research method used a completely randomized design with five levels of fermentation time treatment, 0 days (T0), 1 day (T1), 3 days (T3), 5 days (T5), and 7 days (T7). The observed variables were $\mathrm{pH}, \mathrm{DM}$, ash, $\mathrm{CP}, \mathrm{CL}, \mathrm{CF}, \mathrm{Ca}, \mathrm{P}, \mathrm{GE}, \mathrm{TDN}, \mathrm{NFE}, \mathrm{NDF}$, and ADF. The result showed that the length of the fermentation time were significant differences in $\mathrm{pH}, \mathrm{DM}, \mathrm{CP}, \mathrm{CL}, \mathrm{NDF}, \mathrm{Ash}, \mathrm{Ca}$, and GE contents among treatments. DM, CP, NDF and GE content increased in line with the length of fermentation. These changes are probably due to the remaining enzyme activity and various chemical reactions.
\end{abstract}

Keywords: Agricultural waste, Cattle feed, Fermentation, Inoculum, Sago hampas.

\section{INTRODUCTION}

The utilization of agricultural waste raw materials is an alternative effort to sufficient feed for livestock in Indonesia. One of the abundant feedstuffs that have not been used optimally is sago hampas. Sago hampas are waste obtained in sago industrial processes. Sago hampas have potential as feedstuffs because they still have a high starch content [1]. Sago hampas usage problems for feed are the low protein and high crude fiber content, and it causes low palatability and digestibility of sago hampas. It is estimated that sago hampas will only be able to sufficient the basic needs of livestock if given singly.

Many researchers have attempted to increase the nutritional value of feedstuffs by processing technology. Processing of feedstuffs can be done physically, chemically, and biologically, or a combination of them. An easy and inexpensive processing technology applied to sago hampas is fermentation [2]. The basic principle of fermentation is to activate certain microbial activities in order to change the material nature so that a useful fermentation product is produced [3]. Several research results have been carried out on the fermentation treatment of various vegetable feedstuffs, showing that this method can reduce crude fiber. Mixing sago hampas with rumen contents (70:30) fermented with Bacillus amyloliquefaciens at a dose of $2 \%$ for nine days at $40^{\circ} \mathrm{C}$ was reported to reduce crude fiber by $33 \%$ [4].

Currently, the application of sago hampas fermentation is still mostly carried out on a laboratory scale and generally uses an inoculum in the form of a single microorganism. This causes the fermented product to be harvested or utilized after waiting for a long incubation time, usually more than three weeks. This study aimed to evaluate the nutritional quality of fermented sago hampas, which was carried out on a field scale and using multi-microorganism inoculums. 


\section{MATERIALS AND METHODS}

\subsection{Materials}

The material used in this research is dry sago hampas obtained from waste from sago processing in Kalimantan-Indonesia. The inoculum used was from multi-microorganism inoculum with Saus Burger Pakan $^{\circledR}\left(\mathrm{SBP}^{\circledR}\right)$, produced by $\mathrm{CV}$. Agro Indo Utama, Yogyakarta

\subsection{Methods}

\subsubsection{General}

The fermented sago hampas flour production was carried out with five variations of triple treatment, namely control (fermentation with incubation period 0 days) and fermentation with incubation periods of 1,3 , 5 , and 7 days. The fermentation process is carried out anaerobically at room temperature $\left( \pm 30^{\circ} \mathrm{C}\right)$. In the fermentation process, $150 \mathrm{~kg}$ of previously prepared sago hampas was inoculated with SBP multimicroorganism, first activated in a sterile molasses solution (the molasses was dissolved in water and sterilized at $121^{\circ} \mathrm{C}$ for 15 minutes).

The dose of inoculum used was $0.5 \%$ of the water requirement, and the molasses were mixed in a ratio of $10: 1$ with the required amount of inoculum, which was then deposited for 3 hours before being used. Immediately before mixing, the sago hampas was added with urea dissolved in the mixture as much as $0.4 \%$ of the weight of dry sago hampas. The water content of sago hampas during the fermentation process is maintained at around $40 \%$. After the fermentation process, the sago hampas was dried in an oven at $55^{\circ} \mathrm{C}$ for three days (AOAC 2005). Next, the dry sago hampas was grind using a hammer mill to obtain sago hampas flour.

The dried fermented sago flour with all treatments during the incubation period was tested for its content. Analysis of crude protein, crude fat, calcium, phosphorus and Acid Detergent Fiber (ADF) according to AOAC (2012), analysis of water, ash, crude fiber following SNI 01-2891 (1992), analysis of Neutral Detergent Fiber (NDF), Gross Energy (GE), and Total Digestible Nutrient (TDN) based on MP16, MP21, MP41 (BPMSP).

\subsubsection{Statistics}

The design used in this study was a Completely Randomized Design (CRD) with 5 treatments and 3 replications. The treatments were $\mathrm{T} 0$ (control $=0^{\text {th }}$ day of fermentation), $\mathrm{T} 1=1^{\text {st }}$ day of fermentation, $\mathrm{T} 3=3^{\text {rd }}$ day of fermentation, $\mathrm{T} 5=5^{\text {th }}$ day of fermentation, and $\mathrm{T} 7=7^{\text {th }}$ day of fermentation. The research data were tested using the software program R-4.1.0. A further test of the smallest significant difference of Tukey HSD was carried out at the $5 \%$ test level $(\mathrm{p}<0.05)$.

\section{RESULTS AND DISCUSSION}

Proximate analysis is one of the most widely used variables to determine the nutritional quality of feedstuffs. The nutritional content of fermented sago hampas is presented in Table 1 .

The results showed that the length of the fermentation time decreased the $\mathrm{pH}$ value. The quality of fermented sago hampas can be determined from the acidity $(\mathrm{pH})$ value during fermentation. During fermentation, microbes degrade substrate sugars to produce alcohols and organic acids. The fermentation results for 7 days of incubation are in the good and very good categories. This result is in line with the opinion that silage quality can be classified into four $\mathrm{pH}$ criteria there are very good with $\mathrm{pH} 3.2-4.2$, good $\mathrm{pH} 4.2-4.5$, moderate $\mathrm{pH} 4.5-4.8$, and poor $\mathrm{pH}>4.8$ [5]. Water in the fermentation process is needed to support bacterial growth, including as a transport medium for enzyme distribution.

The lowest $\mathrm{pH}$ value was seen on the $5^{\text {th }}$ day of fermentation, which was 4.01 and the highest $\mathrm{pH}$ value on the $0^{\text {th }}$ day of fermentation, which was 5.54. The decrease in $\mathrm{pH}$ indicates that organic acids are formed due to of metabolic excretion by microbes (lactic acid bacteria) and are not utilized so that the longer the quantity is increasing. A rapid decrease in $\mathrm{pH}$ during the first days of fermentation is essential for inhibiting the growth of unwanted microorganisms, reducing protease and deaminase activity of plant tissues and microorganisms, and preventing Dry Matter (DM) loss $[6,7,8]$.

The decrease in $\mathrm{pH}$ is expected to limit protein breakdown by activating protease enzymes and inhibiting the growth of unwanted microbes, namely Enterobacteria and Clostridia [9]. The decrease in $\mathrm{pH}$ of fermented products is caused by acid secretion [10]. $\mathrm{pH}$ decrease is also expected to be due to the activity of lactic acid bacteria in the anaerobic fermentation process that grows and develops from the inoculum of multi-microorganisms mixed in the substrate. This is in accordance with the statement that the addition of inoculation in the fermentation process can also accelerate the decrease in $\mathrm{pH}$ [11]. Kung [12] stated that silage $\mathrm{pH}$ is related to lactic acid production in the fermentation process, low $\mathrm{pH}$ reflects high lactic acid production.

The results showed that the length of the fermentation time increased the dry matter content. Fermentation increases the dry matter value by $11.51 \%$. This result shows that anaerobic fermentation does not result in loss of DM because the growth of harmful aerobic microbes is inhibited. Loss of DM can be prevented by accelerating the decrease in $\mathrm{pH}$. 
During the fermentation process, it is suspected that microorganisms grow and multiply so that these microorganisms result in the loss of water contained in the substrate and result in an increase in dry matter.

The reduced water bound by the substrate is caused by the fermentation process that produces heat, where the heat causes some of the water to evaporate. The longer the incubation time, the more feedstuffs that can be overhauled by microbes so that at the end of fermentation, the DM will increase. This increase in $\mathrm{DM}$ is beneficial because it reduces nutrient uptake from the silo and increases feed palatability [13]. This result is different from [14] reported that the DM of fermented sago hampas will decrease, along with the longer incubation time. This reaction occurs due to the saturation of lack of oxygen, carbon, nitrogen and lack of substrate as a nutrient.

Table 1. Nutritional value of sago hampas fermented with SBP inoculum multimicroorganism

\begin{tabular}{|c|c|c|c|c|c|}
\hline \multirow{2}{*}{ Composition } & \multicolumn{5}{|c|}{ Treatment (Length of Fermentation Time/Incubation) } \\
\hline & TO & $\mathrm{T} 1$ & $\mathrm{T3}$ & T5 & $\mathrm{T7}$ \\
\hline $\mathrm{pH}$ & $5.54^{c} \pm 0.04$ & $4.36^{b} \pm 0.05$ & $4.29^{b} \pm 0.09$ & $4.01^{\mathrm{a}} \pm 0.01$ & $4.18^{a b} \pm 0.13$ \\
\hline DM & $58.75^{\mathrm{a}} \pm 0.13$ & $65.02^{c} \pm 0.53$ & $62.68^{b} \pm 0.47$ & $63.29^{b} \pm 1.02$ & $65.51^{c} \pm 0.15$ \\
\hline$C P$ & $2.78^{b} \pm 0.11$ & $1.99^{\mathrm{a}} \pm 0.00$ & $3.93^{d} \pm 0.10$ & $4.23^{\mathrm{e}} \pm 0.11$ & $3.81^{c} \pm 0.18$ \\
\hline$C L$ & $0.32^{b} \pm 0.17$ & $0.14^{a} \pm 0.06$ & $0.11^{\mathrm{a}} \pm 0.05$ & $0.12^{\mathrm{a}} \pm 0.05$ & $0.04^{a} \pm 0.02$ \\
\hline CF & $23.90^{\mathrm{abc}} \pm 0.76$ & $19.98^{\mathrm{a}} \pm 2.41$ & $21.87^{\mathrm{ab}} \pm 1.21$ & $25.00^{b c} \pm 1.54$ & $26.99^{c} \pm 1.35$ \\
\hline NDF & $58.98^{a} \pm 8.18$ & $78.28^{b c} \pm 4.73$ & $66.55^{\mathrm{ab}} \pm 2.89$ & $79.69^{c} \pm 0.72$ & $70.02^{\mathrm{ac}} \pm 3.63$ \\
\hline ADF & $34.48^{\mathrm{ab}} \pm 1.47$ & $28.83^{\mathrm{a}} \pm 2.96$ & $37.16^{\mathrm{b}} \pm 0.82$ & $36.52^{b} \pm 1.18$ & $37.70^{\mathrm{b}} \pm 1.19$ \\
\hline Ash & $8.49^{b} \pm 0.24$ & $5.78^{a} \pm 0.35$ & $9.68^{b} \pm 0.96$ & $5.77^{a} \pm 0.33$ & $6.09^{a} \pm 0.23$ \\
\hline Phosphorus & $0.11 \pm 0.01$ & $0.10 \pm 0.01$ & $0.12 \pm 0.02$ & $0.09 \pm 0.01$ & $0.11 \pm 0.04$ \\
\hline Calcium & $0.27^{\mathrm{a}} \pm 0.01$ & $0.31^{\mathrm{ab}} \pm 0.01$ & $0.33^{b c} \pm 0.03$ & $0.36^{c} \pm 0.01$ & $0.34^{b c} \pm 0.02$ \\
\hline NFE & $60.04^{a} \pm 0.71$ & $68.5^{b} \pm 2.78$ & $59.54^{a} \pm 0.81$ & $60.59^{a} \pm 1.58$ & $58.04^{a} \pm 1.91$ \\
\hline TDN & $70.07^{a} \pm 0.48$ & $76.26^{b} \pm 2.06$ & $69.3^{a} \pm 0.73$ & $71.23^{a} \pm 1.20$ & $69.18^{a} \pm .28$ \\
\hline GE & $3104.32^{\mathrm{a}} \pm 6.17$ & $3269.3^{\mathrm{ab}} \pm 151.04$ & $3335.6^{b} \pm 10.36$ & $3282.8^{b} \pm 97.46$ & $3332.71^{\mathrm{b}} \pm 3.83$ \\
\hline
\end{tabular}

The results showed that the length of the fermentation time increased the $\mathrm{CP}$ content on the $3^{\text {rd }}$, $5^{\text {th }}$ and $7^{\text {th }}$ days. The decrease in CP content immediately on the $1^{\text {st }}$ day of fermentation indicated that microbes use this compound as the main nitrogen source for their growth. Later, the increase in $\mathrm{CP}$ content is expected to be caused by an increase in the amount and activity of microbes in binding nitrogen as a basic material for protein synthesis, The increase in nitrogen levels is very beneficial for bacteria to carry out growth and perform activities optimally.

The increase in $\mathrm{CP}$ is also expected to be due to the addition of protein donated by microbial cells, producing single cell protein (SCP) [15]. This increase in $\mathrm{CP}$ content is in line with the results reported, which used palm oil as a substrate [16, 17, 18]. Increased protein levels in fermentation can also be caused by increased decomposer microbes that die because they cannot survive in acidic conditions [19]. Optimally growing microbes can also cause an increase in CP content by utilizing protein and other mineral mixtures [20]. The increase in $\mathrm{CP}$ can also be caused by the presence of enzymes produced by microbes. The greater the number of microbes, the more enzymes in the form of proteins and single cell proteins are produced [21]
The results showed that the long fermentation time reduced CL content. This indicates that microbes effectively use the fat content in the media for growth. Fat is the second energy reserve after carbohydrates are stored in the form of triglycerol [22]. Lipase enzymes break down Fats into fatty acids and glycerol. The decrease in CL content was expected to be due to lipolytic microbes inhibited by the acidity of the fermentation process. The acids formed from the fermentation process to sufficient levels are inhibitory substances against lipolytic bodies that can damage the material [23].

The results showed that the length of the fermentation time affected the $\mathrm{CF}$ content. This result is also reinforced by the performance of the data from the NDF and ADF analysis. The purpose of fermentation is to convert cellulose into simpler compounds by polymerizing and multiplying microbial proteins so that the relationship between $\mathrm{CP}$ and $\mathrm{CF}$ is always inversely proportional [24]. The degradation of cellulose and hemicellulose caused the decrease in crude fiber by cellulose and hemicellulose enzymes produced by microbes [25]. Cellulose is an enzyme complex consisting of several enzymes that work gradually or together to decompose cellulose and hemicellulose into glucose. The degradation of 
cellulose and hemicellulose in the form of glucose is used as a source of carbon and energy for growth and development. Microbial degradation can convert materials containing $\mathrm{CF}$ such as cellulose and hemicellulose into monosaccharides and disaccharides. This result is in line with the statement that the decrease in $\mathrm{CF}$ occurred because microbial activity during fermentation could produce enzymes that degrade CF substrates [26]. The longer the fermentation, the lower the CF [27].

In addition, the decrease in $\mathrm{CF}$ content is thought to be caused by the addition of certain ingredients such as molasses and rice bran. A decrease in CF and Nitrogen Free Extract (NFE) levels will increase in CP levels. The increase in CF content on the $5^{\text {th }}$ and 7 th day of fermentation was closely related to the increase in fermentation time, thus providing an opportunity for anaerobic microbes to grow and develop well. The increase in $\mathrm{CF}$ was caused by the formation of polysaccharides from the microbial origin and was influenced by fluctuations in the substrate's water content during fermentation. Microbial polysaccharides are carbohydrate polymers with high molecular weight [28]. Changes in water content will cause changes in the dry weight of the material affecting the calculation of $\mathrm{CF}$ content in proximate analysis. Another possibility is CF increase caused by the condition of the substrate, namely the availability of starch in the sago hampas. This result allows anaerobic microbes to degrade starch which is easier to digest than $\mathrm{CF}$.

The results showed that the length of fermentation time affected the levels of NDF and ADF. NDF consists of cellulose, hemicellulose, lignin, silica and cutin. ADF consists of cellulose and lignin. ADF content is an estimated value of the fiber fraction that is difficult to degrade by microbes in the rumen [29]. The basic difference in the components of the fiber fraction between NDF and ADF is the hemicellulose content [30]. Cellulose is used by ruminants as the main energy source to support growth, production and reproduction. Cellulose in the cell wall is mostly bound to lignin and hemicellulose to form lignocellulose [31]. Hemicellulose is not expected to be degraded because it is a polysaccharide with a better degradation rate than cellulose and lignin.

Changes in the increase in NDF content are expected to be due to the microbial fermentation process that can break the fiber wall in sago hampas. In addition, it is possible to use components of cell contents that contain fat, sugar, organic acids, nonprotein nitrogen, pectin, dissolved protein, and other water-soluble materials [32]. Microbes during the fermentation process will decompose and simultaneously utilize the cell's contents, which begins with the activity of the cellulase enzyme to loosen the cell walls of the sago hampas. This condition is expected to cause fluctuations in the increase and decrease in NDF and ADF of fermented sago hampas.
Different results showed that fermented and ammoniated rice straw decreased in NDF, ADF, cellulose and lignin [33, 34]. The decrease in the levels of NDF and ADF occurred because during the fermentation the lignocellulosic bonds were broken and microbial activity developed.

The results showed that the length of the fermentation time decreased the ash content except on the $3^{\text {rd }}$ day of fermentation. The mineral or ash content in feedstuffs is absolute because it cannot be converted into other compounds. Changes in the percentage of other nutrients will result in changes in the percentage of ash. The increase in ash content is expected due to the lack of organic matter due to the fermentation process, mainly CF and NFE. This decrease in ash content usually occurs because there will be an increase in organic matter, due to microbes' degradation process of material (substrate). The less organic matter is degraded, the relatively less is the proportional decrease in ash content. On the other hand, the more organic matter is degraded, the more the ash content will increase proportionally.

The results showed that the length of the fermentation time only increased the level of NFE on the $1^{\text {st }}$ day of fermentation. NFE contains hemicellulose, starch, fructan sugar, organic acids, pigments, and water-soluble vitamins. The increase in NFE on the $1^{\text {st }}$ day of fermentation indicates that there has been optimal microbial growth to degrade $\mathrm{CF}$, which produces simple sugar compounds. Some of these simple sugar compounds will be used for microbial activity and partly counted as NFE [35]. This contribution of $\mathrm{CF}$ degradation will cause an increase in NFE levels. NFE is a soluble carbohydrate that is the fastest to digest and a source of energy available for microbes [36].

In the fermentation process, microbes will first use easily digestible energy sources (NFE) before the microbes perform their primary functions [37]. After growing and adapting, the new microbes will then degrade the substrate according to their nature. The decrease in NFE on the next day of fermentation was due to using microbes as energy and carbon structure for their growth. The more microbial growth and the longer the fermentation process will reduce the level of NFE [38]. The best energy concentration, indicated by the combination of the TDN value and the GE of the substrate, was found in fermented sago hampas.

\section{CONCLUSION}

The incubation time for anaerobic fermentation of sago hampas resulted in a clear change in the composition of $\mathrm{pH}, \mathrm{DM}, \mathrm{CP}, \mathrm{CL}, \mathrm{NDF}, \mathrm{NFE}$, and GE values. These changes are probably due to the remaining enzyme activity and various chemical reactions 


\section{ACKNOWLEDGMENTS}

This research was financial supported by Indonesian Agency for Agricultural Research and Development and Indonesian Agency for National Research and Innovation

\section{REFERENCES}

[1] L. Muhsafaat, H.A. Sukria, Suryahadi, Protein quality and amino acid composition of fermented sago pulp (FSP) by Aspergillus niger with urea and zeolit addition, JIPI 20(2) (2015) 124-130. DOI: 10.18343/jipi.20.2.124

[2] P.K. Sadh, D. Surekha, S.D. Joginder, Agroindustrial wastes and their utilization using solid state fermentation: a review, Bioresources and Bioprocessing 5:1 (2018) 1-15. DOI: $10.1186 / \mathrm{s} 40643-017-0187-\mathrm{z}$

[3] G.P.A.W. Kusuma, K.A. Nocianitri, I.D.P.K. Pratiwi, Effect of fermentation time on the characteristics of fermented rice drink as probiotic drink with Lactobacillus sp. F213 isolates, Jurnal Itepa 9(2) (2020) 181-192.

[4] Wizna, A. Hafil, R. Yose, D. Abdi, K. Putu. 2008. Improving the quality of sago pith and rumen content mixture as poultry feed through fermentation by bacillus amylo liquefaciens, Pak J Nutr. 7(2) (2008) 249-254.

[5] M.E. McCollough, Ruminant Nutrients. Rome: Food and Agricultural Organization of Limited Nation, 1978.

[6] J.L. Ellis, I.K. Hindrichsen, G. Klop, R.D. Kinley, N. Milora, A. Bannink, J. Dijkstra, Effects of lactic acid bacteria silage inoculation on methane emission and productivity of Holstein Friesian dairy cattle, J. Dairy Sci. 99 (2016) 7159-7174. DOI: https://doi.org/10.3168/jds.2015-10754.

[7] L. Kung, R.D. Shaver, R.J. Grant, R.J. Schmidt, Silage review: interpretation of chemical, microbial, and organoleptic components of silages, J. Dairy Sci. 101 (2018) 4020-4033. DOI: https://doi.org/10.3168/jds.2017-13909

[8] R.E. Muck, E.M.G. Nadeau, T.A. McAllister, F.E. Contreras-Govea, M.C. Santos, and L. Kung Jr, Silage review: recent advances and future uses of silage additives, J. Dairy Sci. 101 (2018) 3980-4000. DOI: https://doi.org/10.3168/jds.2017-13839

[9] L. Kung, Silage fermentation and additives, in: Direct-fed Microbial Enzyme and Forage Additive Compendium, Miller Publishing Co., Minnetonka, 2001.
[10] M. Makela, S. Galkin, A. Hatakka, T. Lundell, Production of organic acids and oxalate decarboxylase in lignin-degrading white rot fungi, Enzymes and Microbial Technology 30 (2002) 542-549. DOI: https://doi.org/10.1016/S0141-0229(02)00012-1

[11] R.E. Muck, Recent advances in silage microbiology, Agric Food Science 22(1) (2013) 3-15. DOI: https://doi.org/10.23986/afsci.6718

[12] L. Kung, R. Shaver, Interpretation and use of silage fermentation analysis reports, J Focus on Forage 3(13) (2001) 1-5.

[13] C. Tobía, E. Villalobos, A. Rojas, H. Soto, K.J. Moore, Nutritional value of soybean (Glycine $\max$ L. Merr.) silage fermented with molasses and inoculated with Lactobacillus brevis 3, Livestock Research for Rural Development 20(7) (2008).

[14] Sugiyono, Protein and crude fiber content of fermented sago hampas (Metroxylon $s p$ ) with different ripe time, Inkoma Scientific Journal 19(1) (2008) 20-28.

[15] E.A. Iyayi, Changes in the cellulose, sugar and crude protein content of agro-industrial byproducts fermented with Aspergillus niger, Aspergillus flavus and Penicillium sp., African Journal of Biotechnology 3(3) (2004) 186-188. DOI: http://dx.doi.org/10.5897/AJB2004.0002033

[16] T. Pasaribu, A.P. Sinurat, T. Purwadaria, Supriyati, H. Hamid, Improving the nutritive value of palm oil sludge by fermentation: The effect of fungi strain, environmental temperature and enzymatic process, JITV 3(4) (1998) 237-242.

[17] T. Purwadaria, A.P. Sinurat, Supriyati, H. Hamid, I.A.K. Bintang, Evaluation of the nutritional value of fermented palm oil sludge with Aspergillus niger after the drying process by heating, JITV 4(4) (1999) 257-263.

[18] Noferdiman, Y. Ahmad, The nutritious content fermentation of palm oil sludge by $P$. chrysosporium. J. Agripet 13 (2) (2013) 47-52.

[19] A. Asngad, Suparti, Fermentation length and different yeast dosage in the fermentation of dried cassava (Manihot utilissima, Pohl) with Mukibat variety toward bioethanol and glucose content, Jurnal Penelitian dan Teknologi 10(1) (2009) $1-9$.

[20] I.P. Kompiang, A.P. Sinurat, S. Kompiang, T. Purwadaria, J. Darma, Nutrition value of 
protein-enriched cassava: Cassapro, Jurnal Ilmu Ternak and Veteriner 7(2) (1994) 22-25.

[21] Mirnawati, G. Ciptaan, Ferawati, Improving the quality and nutrient content of palm kernel cake through fermentation with Bacillus subtilis. Livestock Research for Rural Development 31(7) (2019).

[22] A.H.A. Toha, Biochemistry: Biomolecular Metabolism, Alphabeta, Bandung, 2005. pp. 99121.

[23] S. Darmosuwito, Some Microbiological Aspects of Fermentative Food, UGM, Yogyakarta, 1985.

[24] Komar, Rice Straw Processing Technology as Animal Feed, Yayasan Dian Grabuta Indonesia, 1984.

[25] Sudharmono, A.W. Ekawati, D. Setijawati, Fermented cassava peel evaluation, International Journal of Chem Tech Research 9(7) (2016) 421-426.

[26] Yunilas, The role of indigenous microorganisms YL (MOIYL) as inoculum for fiber degradation based on palm oil plantation waste, in: Proceedings of the National Seminar on Sustainable Livestock, Sumedang, Indonesia, 2016.

[27] D. Purwanto, The adding of Urea, Phanerochaete chryssporium, and Trametes Sp. To the Content of Crude Fiber of Leaves Stem of Oil Palm as Pasture Feeding, Thesis Faculty of Agriculture, Lampung University, 2012.

[28] A. Martina, N. Yuli, M. Sutisna, Optimization of several physical factors on the degradation rate of Albasia Wood Cellulose Paraserianthes falcataria (L.) Nielsen and Carboxymethyl Cellulase (CMC) Enzymatically by Fungi, Journal of Natur Indonesia 4(2) (2002) 156-63.

[29] Kustantinah, B. Suhartanto, S. Padmowijoto, S.S. Bintaro, Availability of plant cell wall fractions (NDF and ADF) estimated in sacco for dairy cows in dry conditions, in: Proceedings of the National Seminar on the $39^{\text {th }}$ Anniversary of the Faculty of Animal Science, UGM, Yogyakarta, Indonesia, 2008.

[30] I.K. Hindrichsen, M. Kreuzer, J. Madsen, K.E.B. Knudsen, Fiber and lignin analysis in concentrate, forage, and feces: Detergent versus enzymatic-chemicalm, J. Dairy Sci. 89 (2006) 2168-2176.

DOI: https://doi.org/10.3168/jds.S00220302(06)72287-1

[31] L.R. Lynd, P J. Weimer, W.H.V. Zyl, I.S. Pretorius. 2002. Microbial cellulose utilization: fundanmentals and biotechnology, Microbiol. mole. Biol. Rev. 66(3) (2002) 506-577. DOI: http://dx.doi.org/10.1128/MMBR.66.3.506577.2002

[32] Suparjo, K.G. Wiryawan, E.B. Laconi, D. Mangunwidjaja, Chemical Composition Response of Cocoa Pod Incubated with Phanerochaete chrysosporium on Manganese and Calcium Supplementation, Media Peternakan 32(3) (2009) 203-210.

[33] I. Sangadji, The quality of sago by product fermented with white mushrooms (Pleurotus ostreatus) on different harvest times, Agrinimal 7(2) (2019) 69-76.

[34] M. Amin, S.D. Hasan, O. Yanuarianto, M. Iqbal, Effect of fermentation duration on quality of ammoniation of rice straw with probiotic Bacillus Sp., JITPI. 1(1) (2015) 8-13.

[35] S.P. Arora, Microbial Digestion in Ruminants, UGM Press, Yogyakarta, Indonesia, 1995.

[36] A. Mujnisa, In vitro dry matter digestibility, molar proportion of volatile fatty acids and gas production in cocoa pods, kapok seeds, passion fruit peels and passion fruit seeds. Buletin Nutrisi dan Makanan Ternak 6(2) (2007) 31-36.

[37] R.M. Berka, N. Dunn-Coleman, M. Ward, Industrial enzymes from Aspergillus Species, Biotechnology 23 (1992) 155 - 202.

[38] B.I.M. Tampoebolon, Study of differences levels and duration of fermentation of sago waste by Aspergillus niger to crude protein and crude fiber content, in: National Seminar on Livestock Revival, Diponegoro University, Semarang, Indonesia, 2009. 